Tarbawy : Jurnal Pendidikan Islam

ISSN : 2407-4462 (Cetak), 2614-5812 (Elektronik)

Vol. 8, No. 1, 2021, Hal. 38-46

DOI: https://doi.org/ 10.32923/tarbawy.v8i1.1607

\title{
Information Technology System dan Self Esteem Sebagai Solusi Pembelajaran Islam Kontemporer di Era Globalisasi
}

\author{
Rabian Syahbana ${ }^{1}$, Sinta $\mathbf{S}^{2}$ \\ ${ }^{1}$ SDN 05 Namang Bangka Tengah \\ ${ }^{2}$ ISB Atma Luhur Pangkalpinang
}

\section{Info Artikel :}

Diterima 2 februari 2021

Direvisi 20 maret 2021

Dipublikasikan 30 april 2021

\section{Kata Kunci:}

Sistem Teknologi Informasi

Harga diri

Islam kontemporer

Globalisasi

\begin{abstract}
ABSTRAK
Di era globalisasi ini, terjadi perubahan yang luar biasa dalam pola kehidupan manusia. Berkat perkembangan teknologi yang berkembang sangat pesat, khususnya teknologi perangkat komputer dan teknologi perangkat telekomunikasi. Teknologi informasi dan komunikasi merupakan salah satu pendorong utama globalisasi. Sistem teknologi dan kepercayaan memiliki hubungan yang saling terkait satu sama lain. Karena teknologi informasi saat ini merupakan kebutuhan yang sangat penting bagi manusia, karena merupakan salah satu cara bagi manusia untuk mengenal dirinya sendiri dan dunia luar dirinya dalam menghadapi gobalisasi. Islam kontemporer sebagai awal dan karya kreatif untuk menciptakan tradisi Islam baru setelah umat Islam mengalami kekalahan dalam perjuangan politik. Kecuali dengan kemampuan teknologi informasi dan harga diri seseorang mampu menyampaikan ide, gagasan dan pengetahuan tentang agama Islam kepada orang lain. Sistem teknologi informasi dan harga diri menjadi kebutuhan dalam menerapkan pembelajaran agama Islam kontemporer era gobalisasi. Perkembangan sistem teknologi informasi yang selalu bergerak harus diikuti dan diimbangi oleh umat Islam agar tetap menjadi manusia yang berkualitas. Umat Islam dituntut untuk dapat memanfaatkan teknologi informasi dengan sebaik-baiknya sehingga memiliki kepercayaan diri yang tinggi dalam mengkaji agama Islam di era globalisasi saat ini
\end{abstract}

\section{.ABSTRACT}

This globalization era, tremerndous changes occured in the pattern of human life. Thanks to the development of the technology is growing very rapidly, especially the technology of computer equipment and telecomunications equipment technology. Information and communication technology is a key enabler of globalization. Technology systems and confidence have interlocking relationships between one another. Because the current information technology is a very important that human need, because it is one way for people to get to know themselves and the world outside themselves in the face of gobalization. Contemporary Islam as a begining and creative work to create a new Islamic tradition after the Muslims suffered defeat in the political struggle. Excepted with the capabilities of information technology and self-esteem a person is able to convery ideas, ideas and knowledge of the religion of Islam to others. Information technology systems and self-esteem become a necessity in applying contemporary Islamic religious learning era of gobalization. Development of information technology systems that always moves must be followed and offset by Muslims to remain a quality human. Muslims are required to be able use information technology as well as possible so as to have high confidence in the study of the Islamic religion in the current era of globalization.

\section{Koresponden:}

Rabian Syahbana, Sinta S

Email: rabiansyahbana@gmail.com,s.sinta195@gmail.com

Pendahuluan

\section{Latar Belakang}

Dalam kehidupan suatu negara, pendidikan memegang peranan yang amat penting untuk menjamin kelangsungan hidup negara dan bangsa, karena pendidikan merupakan wahana untuk meningkatkan dan mengembangkan kualitas sumber daya manusia. Seiring dengan perkembangan teknologi komputer dan teknologi informasi. Pemanfaatan teknologi informasi di bidang pendidikan dapat memberikan manfaat 
dalam meningkatkan pengelolaan data bagi manajemen pendidikan. Karena itulah peran teknologi informasi sangat dibutuhkan untuk umat Islam sebagai solusi pembelajaran agamanya.

Islam sangat menghargai kemodernan, perkembangan, dinamika sejarah, perubahan, dan keterbukaan. Di sisi lain, Islam menetapkan berbagai aturan dan hukum agar dalam peruahan yang bagaimanapun esensi dan eksistensi Islam yang totalitas dan komprehensif tetap terjaga tanpa diwarnai kondisi yang pecah belah dan kacau balau. Terutama, untuk nilai-nilai material dan spritual yang mengakar pada tauhid murni, bertanggung jawab atas tugas orang, serta komitmen terhadap akhlak serta nilai-nilai ukhrawi. Karena itulah, modernisasi serta kemajuan dalam Islam tidak berdiri di atas kehampaan dan tidak didominasi oleh dimensi material.

Ilmu pengetahuan dan teknologi informasi di era globalisasi menjadi panutan dan mesti dipelajari. Perkembangan ilmu pengetahuan dan teknologi informasi mengalami perkembangan yang sangat pesat dan mesti dipantau terus perkembangannya secara intens. Untuk menghadapi era globalisasi ini dibutuhkan kualitas manusia yang memiliki kemampuan dalam hal kemampuan intelektual, vokal, maupun tanggung jawab kemanusiaan.

Manusia juga diharapkan mempunyai kepercayaan diri agar tujuan yang diharapkan dapat tercapai dalam pembelajaran Islam kontemporer. Pembelajaran untuk menghadapi era globalisasi dirasakan sangat penting untuk dapat menciptakan manusia-manusia yang berkualitas baik secara jasmani maupun rohani. Oleh karena itu, dibutuhkan solusi pembelajaran demi peningkatan mutu terutama untuk peningkatan kualitas sumber daya manusia.

\section{Perumusan Masalah}

Berdasarkan latar belakang diatas maka perumusan masalah yang harus di ketahui diantaranya adalah pengertian information technology system dan self esteem dan hubungan antara information technology system dan self esteem sebagai solusi pembelajaran Islam kontemporer di era globalisasi.

\section{Tujuan Penelitian}

Tujuan dari pembahasan jurnal ini adalah agar mengetahui pengertian information technology system dan self esteem dan hubungan antara information technology system dan self esteem sebagai solusi pembelajaran Islam kontemporer di era globalisasi.

\section{Kajian Literatur}

\section{Kajian Teori}

Pembahasan tentang information technology system dan self esteem sebagai solusi pembelajaran Islam kontemporer di era globalisasi belum ada yang membahasanya, kalaupun ada belum di temukan atau kurang terekpos. Tapi jika jurnal atau buku yang membahas tentang sistem teknologi informasi dan kepercayaan diri sudah banyak. Diantaranya oleh Kathryn James dan Christine Nightingale dalam jurnal mereka yang berjudul "Self-Esteem, Confidence and Adult Learning" lalu oleh mahasiswa Universitas Gajah Mada yaitu Siska, Sudardjo, dan Esti Hayu Purnamaningsih dalam jurnal mereka yang berjudul "Kepercayaan Diri Dan Kecemasan Komunikasi Interpersonal Pada Mahasiswa".

\section{Hasil Penelitian}

Dari dua contoh jurnal yang diambil diatas masing-masing jurnal membahas keunggulannya masingmasing. Kathryn James dan Christine Nightingale dalam jurnal mereka yang berjudul "Self-Esteem, Confidence and Adult Learning" membahas secara garis besar tentang kepercayaan diri seseorang. Kesimpulan dari jurnal mereka adalah self-esteem and confidence, though often used interchangeably, are different. Self-esteem relates to our feelings of worth and to our feelings of competency and effectiveness, and importantly, to the interconnectedness between those two feelings, which will impact on how we act and behave. Confidence generally relates to our beliefs about our abillites and attributes about specific aspects of ourselves or in particular situations. Confidence and self-esteem levels change in respone to situations and life events, and how we deal with them. Establishing a definition of self-esteem and confidence is necessary before taking any action to promote positive self-esteem and confidence, and knowing what you want those changes to lead to.

Sedangkan jurnal mahasiswa Universitas Gajah Mada yaitu Siska, Sudardjo, dan Esti Hayu Purnamaningsih yang berjudul "Kepercayaan Diri Dan Kecemasan Komunikasi Interpersonal Pada Mahasiswa" merupakan jurnal penelitian sehingga mempunyai kesimpulan bahwa Analisis terhadap data penelitian menghasilkan koefisien korelasi sebesar -0,725 dengan $\mathrm{p}<0,01$ yang berarti ada hubungan negatif yang signifikan antara kepercayaan diri dengan kecemasan komunikasi interpersonal. Berarti semakin tinggi kepercayaan diri, maka semakin rendah kecemasan komunikasi interperso-nalnya, begitu pula sebaliknya. Sementara dari uji t diperoleh hasil sebesar - 0,678 dengan $p>0,05$ yang berarti tidak ada perbedaan kecemasan komunikasi interper-sonal yang signifikan antara subjek perempuan dan laki-laki. 
Jurnal "Kepercayaan Diri Dan Kecemasan Komunikasi Interpersonal Pada Mahasiswa" di dapat dari hasil subjek penelitian mereka adalah mahasiswa Program Studi Manajemen Fakultas Ekonomi Universitas Kristen Imanuel (UKRIM) Yogyakarta. Jumlah subjek 118 orang, terdiri dari 61 orang mahasiswi dan 57 orang mahasiswa. Data dikumpulkan dengan mengguna-kan dua (2) skala, yaitu Skala Kepercayaan Diri yang terdiri dari 43 aitem, yang merupakan modifikasi dari The Test of SelfConfidence yang disusun oleh Peter Lauster (1978), dan Skala Kecemasan Komunikasi Interpersonal yang terdiri dari 57 aitem, dimodifikasi dari skala yang disusun oleh Syarani (1995) berdasarkan aspek-aspek kecemasan yang dikemukakan oleh Sue (1986). Data dianalisis dengan menggunakan korelasi moment tangkar dan uji t, dengan bantuan Seri Program Statistik (SPS) edisi Sutrisno Hadi dan Seno Pamardiyanto.

Kedua jurnal diatas bisa digunakan sebagai kerangka acuan dalam pembahasan kali ini yaitu tentang information technology system dan self esteem sebagai solusi pembelajaran Islam kontemporer di era globalisasi. Pembahasan jurnal kali ini membahas tentang information technology system dan self esteem yang lebih difokuskan tentang agama Islam. Dimana perkembangan information technology system dan self esteem saat ini sangatlah pesat sehingga pembelajaran Islam kontemporer di era globalisasi dapat dilakukan dengan baik.

\section{Pembahasan}

Dalam berkomunikasi secara efektif di era globalisasi seluruh muslim dituntut agar dapat mempelajari dan menyampaikan agama Islam. Berbeda dengan masa lalu dimana tingkat kesulitan informasi tidak seperti sekarang. Sistem informasi saat ini sangatlah pesat, jika terlambat sedikit saja maka akan tertinggal. Islam mesti dihadirkan dalam bentuk modern sehingga tidak dianggap sebagai agama yang ketinggalan zaman. Tidak bisa dipungkiri kenyataan saat ini masih ada muslim yang mengalami kesulitan dalam berkomunikasi dengan orang lain (komunikasi interpersonal), dalam menyampaikan agamanya baik dalam saat berkumpul dengan komunitasnya sendiri maupun saat berada di tengah-tengah masyarakat. Perasaan cemas saat berbicara di depan umum dikarenakan kurangnya rasa percaya diri. Seseorang yang melakukan komunikasi di depan umum sering kali menjadi cemas karena kepercayaan diri yang dimilikinya rendah.

Mcleod Jr dan Scheell (2008: 49) berpendapat, misi teknologi informasi adalah untuk memberikan layanan informasi dengan kualitas terbaik di dalam suatu lingkungan pendukung yang akan mempromosikan kreativitas, perkembangan pribadi, interaksi, keberagaman, dan pengembangan profesional sehingga perusahaan dapat memanfaatkan teknologi guna membantu mencapai tujuan-tujuan korporat.

Mulyono (2008: 1-2) menyebutkan bahwa di era globalisasi ini, perubahan yang sangat dahsyat terjadi pada pola kehidupan manusia. Pola kehidupan manusia yang telah terbingkai dalam sistem sosial budaya dengan adat istiadat dan agama telah mengalami pengikisan secara hebat hingga mengakibatkan perubahan yang sangat drastis. Di sisi lain yang mencoba mempertahankan akan mengalami benturanbenturan sosial yang tak jarang berakhir pada kekacauan.

Piliang (2003: 256) mengemukakan globalisasi telah berkembang menjadi globalisme-jiwa, sikap dan gaya hidup yang telah mengglobal. Pengembaraan global tidak lagi dipandang sebagai suatu keterpaaksaan, melainkan sebagai satu kemutlakan, sebaga konsekuensi logis dari globalisasi itu sendiri. Akan tetapi, globalisasi bukannya tanpa risiko. Salah satu risiko globalisasi adalah semakin merosotnya peran lembaga negara bangsa (nation state) di dalam interaksi global serta semakin sulitnya pemerintah (goverment) mengontrol akibat-akibat kerumitan yang dimunculkan oleh lenyapnya berbagai batas negara, bangsa, teritorial, dan kultural.

Misi teknologi informasi akan dapat dapat tercapai dengan mengejar sasaran-sasaran seperti membangun suatu keunggulan kompetetif dalam penggunaan teknologi informasi, mengembangkan sistem informasi yang memenuhi kebutuhan karyawan di selutuh tingkat organisasi dan juga para mitra lingkungan bisnis, tetap mengikuti perkembangan teknologi informasi sehingga dapat memenuhi kebutuhan para pelanggan, mempertahankan stabilitas operasional dan keandalan bagi seluruh sumber daya informasi yang ada, orang, data, fasilitas, peranti keras, dan peranti lunak, dan menjaga kesinambungan program pendidikan dan pelatihan yang dirancang untuk meraih penggunaan seluruh sumber daya informasi secara efesien dan efektif.

Untuk lingkup layanan teknologi informasi terdiri atas layanan administrasi (tinjauan anggaran dan fiskal, sumber daya manusia, pelaporan manajemen, dan hubungan pemegang saham) dan Layanan Teknis (perencanaan strategis dan implementasi, perencanaan kapasitas, rancangan jaringan, pemeliharaan, penanganan masalah, dan administrasi, instalasi server, dan perencanaan kontinjensi dan backup). 
Amsyah (2005:1) menyebutkan bahwa berkat perkembangan ilmu (science) maka teknologi (technology) berkembang sangat pesat, terutama teknologi peralatan komputer dan teknologi peralatan telekomunikasi. Teknologi komputer dan telekomunikasi telah membawa manusia ke dalam era informasi yang mengalir tanpa batas. Informasi diperlukan manusia untuk menyelesaikan berbagai keperluan hidupnya, termasuk kehidupannya di dalam pekerjaan organisasi. Pekerjaan informasi inilah yang mendukung setiap kegiatan manusia.

Teknologi informasi dan komunikasi adalah faktor pendukung utama dalam globalisasi. Perkembangan teknologi begitu cepat sehingga informasi dengan berbagai bentuk dan kepentingan dapat tersebar luas ke seluruh dunia. Oleh karena itu, globalisai tidak dapat kita hindari kehadirannya. Menginjak tahun 2000-an, salah satu fenomen globalisasi yang terjadi adalah kian merebaknya penggunaan handphone dan internet (E-Mail, Web-blog, Friendster, fb, dan sebagainya; yang merambah ke mana-mana dan segenap lapisan masyarkat. Jatmika (2010: 96) mengemukakan internet dan era globalisasi sangat erat hubungannya. Dengan internet, setiap orang dapat mendunia alias masuk ke dalam era globalisasi.

Berkat teknologi informasi yang baik seseorang bisa mempunyai kepercayaan diri yang tinggi akam memiliki keyakinan atas kemampuan yang ada dalam dirinya sendiri saat akan melakukan kegiatan komunikasi di depan umum. Ia akan menyampaikan segala sesuatu dengan penuh keyakinan dan merasa bangga ketika apa yang disampaikannya di respon dengan baik oleh audiens.

Sehingga menurut Suparno (2002: 91) menyebutkan bahwa globalisasi telah menciptakan dunia yang semakin terbuka dan adanya saling ketergantungan antarnegara dan antarbangsa, karena itu semua negara akan terbuka pula terhadap pengaruh globalisasi, termasuk di dalamnya adalah tatanan nilai yang dianut suatu bangsa.

Fatta (2007: 3) berpendapat sistem dapat diartikan sebagai suatu kumpulan atau himpunan dari unsur atau variable-variable yang saling terorganisasi, saling berinteraksi, dan saling bergantung sama lain. Lalu Amsyah (2005: 2) menyebutkan bahwa informasi adalah data yang sudah diolah, dibentuk, atau dimanipulasi sesuai dengan keperluan tertentu.

Sistem teknologi informasi dan kepercayaan diri mempunyai hubungan yang saling berkaitan antara satu dengan yang lainnya. Dikarenakan teknologi informasi saat ini merupakan kebutuhan manusia yang sangat penting, karena merupakan salah satu cara bagi manusia untuk bisa mengenal dirinya dan dunia di luar dirinya dalam menghadapi era globalisasi. Sehingga dengan kemampuan yang dimiliki tersebut seseorang mampu menyampaikan ide, gagasan dan pengetahuan agama Islam kepada orang lain. Kegiatan komunikasi merupakan hal yang sangat penting dalam kehidupan sehari-hari, meskipun demikian sebagian orang masih mengalami kesulitan dalam hal berkomunikasi. Salah satu bentuk kesulitan tersebut adalah kecemasan untuk mengungkapkan apa yang hendak diinformasikan kepada orang lain.

Kebutuhan sistem informasi para pengguna dipenuhi melalui dua fungsi yang saling berhubungan: pengembangan sistem dan pemeliharaan sistem. Singleton (2007: 62) menyebutkan bagian yang pertama bertanggung jawab untuk menganalisi berbagai kebutuhan pengguna dan mendesain sistem baru yang dapat memnuhi berbagai kebutuhan tersebut. Para partisipan yang terlibat dalam aktivitas pengembangan sistem meliputi para praktisi sistem, pengguna akhir, dan pemegang kepentingan.

Komunikasi interpersonal adalah suatu bentuk interaksi antara orang dengan orang lainnya yang bertujuan untuk saling bertukar informasi dan menerima informasi. Setiap orang yang percaya diri biasanya selalu bersikap optimis dan yakin akan kemampuannya dalam melakukan sesuatu termasuk dalam hal berinteraksi dengan berkomunikasi.

Komunikasi interpersonal terjadi ketika seseorang berkomunikasi secara langsung dengan orang lain dalam situasi satu-satu atau dalam kelompok-kelompok kecil. Saat seseorang muslim berkomunikasi dengan orang lain tentang suatu informasi agama, gagasan dan sikapnya di depan orang lain mesti di jaga. Komunikasi dibutuhkan agar seseorang dapat memahami, mendengar, dan mampu memahami masyarakat. Kepercayaan diri dapat dilatih atau dibiasakan. Diketahui kemampuan komunikasi interpersonal dibagi menjadi 2 kategori yaitu baik dan buruk. Salah satu kemungkinan besar yang menjadi penyebab terjadinya kesulitan komunikasi interpersonal adalah adanya kecemasan diantaranya adalah rasa takut menerima tanggapan atau penilaian negatif dari komunikan atau orang yang menerima pesan.

Masalahan utama dalam kepercayaan diri adalah adanya rasa khawatir tentang respon atau penilaian orang lain terhadap dirinya, mengenai apa yang disampaikannya dan bagaimana ia menyampaikannya. Sikap inilah yang menjadi salah satu ciri dari orang yang kurang percaya diri. Bagaimana cara seseorang menghadapi orang lain dipengaruhi oleh bagaimana ia memandang dirinya. Respon-respon saat berkomunikasi dengan seseorang sering merupakan refleksi dari kognisinya terhadap diri sendiri. 
Ada tanda-tanda jika seseorang mengalami kecemasan saat berkomunikasi yaitu tingkat psikologis, seperti tegang, bingung, khawatir, sulit berkonsentrasi, dan lain-lain. Dan tingkat fisiologis, yaitu kecemasan yang sudah mempengaruhi fisik, terutama fungsi sistem syaraf seperti sukar tidur, jantung berdebar, keringat berlebihan, sering gemetar dan perut mual.

Kecemasan komunikasi dapat kita bagi dalam empat aspek, pertama kecemasan kognitif yaitu perhatian yang berlebihan terhadap diri sendiri dan juga terhadap pandangan atau penilaian orang lain. Kedua afektif yaitu perasaan malu, gelisah dan bingung. Ketiga perubahan fisiologis, yaitu detak jantung dan nadi meningkat, keringat berlebihan, tangan dan kaki dingin serta perut mulas. Keempat perilaku motorik yaitu bicara terpatah-patah, tidak banyak bicara, gemetaran, kepala menunduk atau berusaha menghindari tatap mata.

Kecemasan itu berwujud ketakutan kognitif, keterbangkitan syaraf fisiologis dan suatu pengalaman subjektif dari ketegangan atau kegugupan. Ciri-ciri seseorang mempunyai kecemasan komunikasi, seperti ketakutan sebelum dan selama aktivitas atau kegiatan berlangsung, pembangkitan fisiologis (kegelisahan yang ditimbulkan oleh meningkatnya aktivitas sistem saraf otonom), pembangkit reaksi subjektif pada diri orang, tidak dapat mengendalikan perasaan, ketakutan atau kecemasan dalam menyatakan sesuatu, dan perasaan takut dinilai orang lain. Setiap orang pernah mengalami kecemasan, karenanya kecemasan bukanlah hal yang asing bagi manusia. Walaupun setiap orang pernah mengalaminya, tingkat kecemasan dan reaksi yang dilakukan untuk mengatasinya belum tentu sama, sehingga akibat yang ditimbulkan juga berbeda setiap orang.

Kecemasan komunikasi mempunyai empat aspek, antara lain reaksi-reaksi kognitif, afektif, perubahan fisiologis dan perilaku motorik. Istilah lain kecemasan komunikasi sebagai communication apprehension, yang dapat didefinisikan sebagai suatu kondisi ketika seseorang merasa takut atau cemas untuk melakukan komunikasi, baik formal maupun informal, orangal maupun kelompok. Kecemasan dalam berkomunikasi sebenarnya merupakan bentuk perilaku yang normal bagi setiap orang.

Keadaan seseorang yang seperti ini dianggap mengalami kecemasan sosial. Orang yang memiliki tingkat kecemasan komunikasi sosial lebih tinggi ketika berhadapan dengan orang asing daripada yang mereka lakukan dengan orang yang sudah mereka kenal. Kepercayaan diri diperoleh dari pengalaman hidup. Kepercayaan diri merupakan salah satu aspek kepribadian yang berupa keyakinan akan kemampuan diri seseorang sehingga tidak terpengaruh oleh orang lain dan dapat bertindak sesuai kehendak, gembira, optimis, cukup toleran, dan bertanggung jawab. Kepercayaan diri berhubungan dengan kemampuan melakukan sesuatu yang baik.

Orang yang memandang permasalahan sesuai dengan kebenaran yang semestinya, bukan menurut kebenaran pribadi atau diri sendiri. Kesediaan orang untuk menanggung segala yang telah menjadi konsekuensinya. Analisis terhadap suatu masalah, sesuatu hal, dan suatu kejadian dengan menggunakan pemikiran yang dapat diterima oleh akal dan sesuai dengan kenyataan.

Keadaan orang yang seperti ini dianggap mengalami kecemasan sosial. Dimana salah satu bentuk kecemasan yang sering terjadi adalah kecemasan dalam hal berkomunikasi. Ketika merasa cemas ataupun ketika dihadapkan dengan situasi-situasi yang menekan, orang akan mengalami gejala-gejala fisik maupun psikologis.

Secara umum faktor-faktor yang menyebabkan timbulnya kecemasan adalah faktor internal dan faktor eksternal. faktor internal meliputi rasa pesimis, takut gagal, pengalaman negatif masa lalu, dan pikiran yang tidak rasional. Sementara faktor eksternal seperti kurangnya dukungan sosial, lingkungan pergaulan dan lain-lain.

Orang akan memiliki kecemasan komunikasi yang rendah ketika mereka memiliki kepercayaan diri yang tinggi, begitu juga sebaliknya. Diharapkan nanti setiap orang dapat berpikir secara intelektual dan mampu memaknai secara positif pengalaman dan tantangan dalam dunia luar secara professional. Cara memaknai tantangan tersebut dengan menumbuhkan konsep diri yang positif sehingga akan muncul kepercayaan diri akan eksistensinya dalam menghadapi permasalahan.

Komunikasi menjadi alat utama dalam media pembelajaran karena kelancaraan dalam proses belajar mengajar tergantung dari kelancaran komunikasi itu sendiri. Dengan komunikasi interpersonal, kita bisa memenuhi kebutuhan sosial atau psikologis. Para psikolog pun menyarankan bahwa pada dasarnya kita adalah makhluk sosial, yaitu orang yang membutuhkan orang lain, sebagaimana halnya manusia membutuhkan makanan, minuman, perlindungan dan sebagainya. Melalui komunikasi interpersonal, kita juga akan memperoleh informasi yang lebih.

Takut saat melakukan komunikasi dikenal sebagai communication apprehension. Orang yang aprehensif dalam komunikasi disebabkan oleh kurangnya rasa percaya diri. Untuk menumbuhkan percaya diri, menumbuhkan konsep diri yang sehat menjadi perlu. Tetapi tidak semua aprehensi komunikasi 
disebabkan kurangnya percaya diri, tetapi diantara berbagai faktor yang paling menentukan adalah percaya diri. Hal tersebut dapat dipengaruhi oleh banyak faktor salah satunya adalah kecemasan.

Kecemasan dalam berkomunikasi di depan umum merupakan salah satu ketakutan terbesar yang dialami oleh manusia. Kecemasan ini menghasilkan pengaruh yang negatif terhadap berbagai aspek kehidupan. Kecemasan komunikasi yang dialami seseorang saat akan melakukan komunikasi di depan umum bisa muncul karena kurangnya rasa percaya diri. Perasaan cemas merupakan hal yang wajar bila seseorang mengalami suatu kecemasan saat akan mulai suatu pembicaraan, terutama didepan umum. Bahkan seseorang yang telah berpengalaman berbicara di depan umum pun tidak terlepas dari perasaan ini.

Kecemasan dalam berkomunikasi mempunyai banyak istilah seperti demam panggung (stage fright), kecemasan komunikasi (communication anxiety), kecemasan tampil didepan umum (performance anxiety), dan kemudian berkembang dengan istilah communication apprehension. Communication apprehension ini di definisikan sebagai kecemasan atau ketakutan yang di derita oleh orang secara nyata atau antisipasi komunikasi, baik dalam suatu kelompok atau orang dengan orang. Kecemasan komunikasi merupakan suatu jenis fobia sosial, yang ditandai dengan adanya suatu pemikiran bahwa dirinya akan dikritik atau dinilai jelek oleh orang lain. Orang yang mengalami kecemasan komunikasi akan sedapat mungkin menghindari situasi komunikasi, hal ini karena ia takut orang lain akan mengejeknya atau menyalahkannya.

Kepercayaan diri merupakan sesuatu yang urgen untuk dimiliki setiap orang. Kepercayaan diri diperlukan baik oleh seorang anak maupun orangtua, secara orangal maupun kelompok. seseorang yang memiliki kepercayaan diri meyakini bahwa seseorang mampu menanggulangi suatu masalah dengan situasi terbaik dan dapat memberikan sesuatu yang menyenangkan bagi orang lain.

Orang yang memiliki kepercayaan diri yang tinggi juga memiliki sikap yang objektif dalam memandang sebuah permasalahan sesuai dengan kebenaran semestinya bukan dengan pemikiran pribadinya. Sehingga ketika ia akan melakukan sebuah komunikasi di depan umum maka ia akan menyampaikan segala sesuatu sesuai dengan kebenaran dan fakta. Kemudian orang yang memiliki kepercayaan diri yang tinggi juga memiliki sikap bertanggung jawab yang sehingga ketika dia melakukan suatu kesalahan maka dia akan menerima konsekuensi atas perbuatan yang dilakukannya. Dalam berkomunikasi dengan orang lain kepercayaan diri sangat dibutuhkan, karena pengakuan dan penghargaan dalam berkomunikasi akan kita miliki, jika memiliki kepercayaan diri.

Beberapa orang juga mengalami perasaan tidak nyaman dengan kehadiran orang lain, biasanya disertai dengan perasaan malu, yang ditandai dengan kekakuan, hambatan dan kecenderungan untuk menghindari interaksi sosial. Selain itu rasa percaya diri juga dapat membantu seseorang apabila berhadapan dengan ketidakpastian, membantu melihat tantangan-tantangan sebagai kesempatan-kesempatan, mengambil resiko-resiko yang dapat diperhitungkan, dan membuat keputusan-keputusan dengan tepat.

Tidak semua kecemasan dalam berkomunikasi disebabkan kurangnya percaya diri, tetapi diantara berbagai faktor yang ada yang paling menentukan adalah rasa percaya diri. Kepercayaan diri adalah salah satu aspek kepribadian yang paling penting pada diri seseorang. Tanpa adanya kepercayaan diri akan banyak menimbulkan masalah pada diri. Kepercayaan diri merupakan sifat yang paling berharga pada diri seseorang dalam kehidupan bermasyarakat, dikarenakan dengan kepercayaan diri seseorang mampu mengaktualisasikan segala potensi yang ada pada dirinya.

Ketika ia menyampaikan sesuatu yang salah maka ia akan meminta maaf dan menjelaskan kembali apa yang telah disampaikan dengan benar dan sesuai dengan fakta. Selain itu orang yang memiliki kepercayaan diri yang tinggi juga dalam berkomunikasi di depan umum dapat menyampaikan segala sesuatu yang hendak disampaikan secara rasional dan realistis. Hal ini dapat diartikan bahwa apa yang hendak disampaikan dapat diterima oleh akal dan sesuai dengan kenyataan.

Peran kepercayaan diri sangat penting dalam kehidupan seseorang. Dengan adanya kepercayaan diri seseorang akan mengusahakan dirinya untuk mengembangkan penilaian positif baik terhadap diri sendiri maupun terhadap lingkungan dan situasi yang dihadapi. Kepercayaan diri merupakan petunjuk bahwa seseorang tersebut merasa memiliki kompetensi, yakin mampu dan percaya bahwa dia bisa. Kepercayaan diri merupakan dasar keyakinan seseorang atas kemampuan yang dimilikinya dalam berbagai situasi, ia mampu mendorong dirinya sendiri untuk mengerahkan kemampuannya mencapai tujuan.

Rasa percaya diri adalah keyakinan seseorang akan kemampuan yang dimiliki untuk menampilkan perlaku tertentu atau untuk mencapai target tertentu. Dengan kata lain, kepercayaan diri adalah bagaimana kita merasakan tentang diri kita sendiri, dan perilaku kita akan merefleksikannya tanpa kita sadari. Rasa percaya diri bukan merupakan sifat yang diturunkan (bawaan) dari orang tua tetapi mesti diperoleh dari pengalaman hidup, serta dapat diajarkan dan ditanamkan melalui pendidikan, sehingga upaya-upaya tertentu dapat dilakukan guna membentuk dan meningkatkan rasa percaya diri. Dengan 
demikian kepercayaaan diri dapat terbentuk dan berkembang melalui proses belajar di dalam interaksi seseorang dengan lingkungannya. Sehingga bisa menjadi solusi pembelajaran Islam kontemporer di era globalisasi.

Seseorang yang memiliki keterampilan dalam berkomunikasi maka itu akan menjadi dasar yang baik bagi pembentukan sikap percaya diri. Menghargai pembicaraan orang lain, berani berbicara di depan umum, tahu kapan akan berganti topik pembicaraan dan mahir dalam berdiskusi adalah bagian dari keterampilan komunikasi yang bisa dilakukan jika orang tersebut memiliki rasa percaya diri.

Bisa dikatakan bahwa teknologi informasi merupakan solusi pembelajaran untuk umat Islam di era globalisasi di bidang pendidikan, peranan teknologi informasi sudah tidak dapat dipisahkan lagi. Misalnya sekarang hampir seluruh sekolah baik pemerintah maupun swasta saat ini sedang menerapkan sistem berbasis komputer dalam mengelola data-data yang berhubungan dengan pendidikan seperti data siswa, administrasi, nilai, jadwal pelajaran dan lain sebagainya. Dengan adanya sistem yang terkomputerisasi maka dapat memberikan pelayanan yang baik dan cepat untuk pihak internal maupun eksternal.

Teknologi informasi dimanfaatkan sangat dibutuhkan untuk meningkatkan efisiensi dan produktivitas bagi manajemen pendidikan. Keberhasilan dalam peningkatan efisiensi dan produktivitas bagi manajemen pendidikan akan ikut menentukan kelangsungan hidup institusi pendidikan itu sendiri. Dengan kata lain menunda penerapan teknologi informasi dalam institusi pendidikan berarti menunda kelancaran pendidikan dalam menghadapi persaingan global.

Pemanfaatan teknologi informasi diperuntukkan bagi peningkatan kinerja institusi pendidikan dalam upayanya meningkatkan sumber daya manusia. Dengan demikian dapat memberikan keuntungan pada efisiensi waktu dan tenaga. Penghematan waktu dan kecepatan penyajian informasi akibat penerapan teknologi informasi tersebut akan memberikan kesempatan untuk meningkatkan kualitas komunikasi dan pembinaan. Dengan demikian pembelajaran lebih dalam upaya mengembangkan kepribadian dan pengetahuannya.

Teknologi informasi berguna sebagai database yang merupakan tempat penyimpanan data yang dapat menampung satu atau lebih data. Basis data yang diperlukan oleh sistem harus dirancang terlebih dahulu, perancangan basis data diperlukan agar kita bisa memiliki basis data yang lengkap dan efisien dalam penggunaan ruang penyimpanan, cepat dalam pengaksesan dan mudah dalam pemanipulasian (tambah, ubah, hapus) data.

Keterkaitan data dan informasi sangatlah erat sebagaimana hubungan antara sebab dan akibat. Data merupakan bentuk dasar dari sebuah informasi, sedangkan informasi merupakan elemen yang dihasilkan dari suatu bentuk pengolahan data. Untuk menghasilkan sebuah informasi, terlebih dahulu perlu mengumpulkan data-data agar menghasilkan informasi yang objektif.

Teknologi informasi berperan dalam restrukturisasi terhadap peran manusia. Untuk seluruh umat Islam pada situasi sekarang diharapkan mampu belajar menuntut agama lebih mandiri, aktif, dan berinisiatif dalam mencari informasi. Semua ini dipersiapkan agar setiap muslim bisa menjadi sosok pribadi yang mandiri dan inovatif, sehingga mempunyai kemampuan yang layak dan selalu selangkah di depan saat berinteraksi secara langsung ke masyarakat dalam mengabdikan ilmu agamanya.

Widyatmadja (2005: 93) berpendapat bahwa di era globalisasi ini sedikit orang yang bermimpi untuk menciptakan dunia yang lebih baik. Globalisasi tidak membuat manusia makin terbuka untuk menghargai dan menghormati keberadaan pihak lain yang punya latar belakang berbeda. Praktek globalisasi seirng menjadikan golongan manusia yang rentan harus dikorbankan demi keamanan dan kemakmuran orang atau negara yang sudah mapan.

Saat seseorang merasa rendah diri, dia akan mengalami kesulitan untuk mengkomunikasikan apa yang ingin ia sampaikan pada orang lain. Kemampuan seseorang, termasuk kemampuan komunikasi, tidak hanya ditentukan oleh masalah fisik dan ketrampilan saja, tetapi juga dipengaruhi oleh kepercayaan diri. Salah satu penyebab terjadinya kesulitan komunikasi interpersonal adalah adanya kecemasan seperti rasa takut menerima tanggapan atau ada penilaian negatif dari komunitas atau orang yang menerima pesan. Disinilah peran kepercayaan diri sangat dibuthkan.

Muslim yang kuat dalam berkomunikasi, ia akan memiliki kepercayaan diri yang mandiri, tidak mementingkan diri sendiri, cukup toleran, ambisius, optimis, tidak pemalu, yakin dengan pendapatnya sendiri, tidak berlebihan, dan memiliki sikap yang positif terhadap diri sendiri. Kepercayaan diri dan kemandirian memiliki hubungan yang erat karena orang yang kepercayaan dirinya tinggi umumnya lebih mudah terlibat secara pribadi dengan orang lain dan lebih berhasil dalam hubungan interpersonal.

Kepercayaan diri merupakan suatu konsep yang menarik. Rasa percaya diri yang sejati berarti kita memiliki beberapa hal yang meliputi integritas diri, wawasan pengetahuan, keberanian, sudut pandang yang luas, dan harga diri yang positif. Lumpkin (2004: 83-84) menyebutkan seseorang bisa saja merasa percaya diri, tetapi sekaligus rendah diri. Seseorang mungkin saja memiliki rasa percaya diri, tetapi tidak 
mmpunyai banyak pengaruh. Sebagai contoh, seorang pria dengan pembawaan yang kasar mungkin saja merasa percaya diri dalam berbagai situasi, tetapi ia akan merasa ketakutan setengah mati jika harus berpidato di hadapan sekelompok orang. Orang-orang mungkin takut terhadap pria tadi dan ingin menghindarinya. Sebenarnya pria terseut sungguh-sungguh khawatir dengan penilaian orang dihormati. Rasa percaya diri mereka didasarkan pada pandangan terhadap nilai dari posisi mereka saat itu atau pada hal-hal lain yang sebenarnya tidak nyata. Sementara itu, orang-orag yang lain lagi berpikiran bahwa seluruh dunia dengan sendirinya harus ematuhi dan mempercayai perkataan mereka hanya karena mereka mempunyai latar belakang pendidikan tertentu. Hal yang perlu digarisbawahi adalah walaupun seseorang mungkin tampil percaya diri, hal itu belum tentu berarti ia juga berpengaruh atau disukai oleh orang lain.

Penyebab kepercayaan kemungkinan juga dipengaruhi juga oleh beberapa hal seperti adanya pengaruh faktor lingkungan. Selain itu pembelajaran agama dalam keluarga sudah mulai berubah, dimana kurang begitu diperhatikan terhadap anak laki-laki maupun anak perempuan, sehingga kedua-duanya kurang bisa percaya diri dalam hal beragama. Sehingga munculah kecemasan saat berkomunikasi tentang agama karena takut salah. Kecemasan komunikasi tidak lagi menjadi penghambat dalam mencari informasi jika mempunyai teknologi seperti sekarang, tetapi tetap dibutuhkan perundingan sesuatu dan dalam hal berkerjasama. Bahwa kepercayaan diri merupakan prediktor yang akurat bagi keberhasilan seseorang, disamping kemampuan dan ketrampilan yang dimiliki.

Soedarsono dan Kusuma A (2004: 40) mengungkapkan kepercayaan diri adalah keyakinan untuk melakukan sesuatu pada orang sebagai karakteristik pribadi yang di dalamnya terdapat keyakinan akan kemampuan diri, optimis, objektif, bertanggung jawab, rasional dan realistis. Kecemasan komunikasi di depan umum adalah pengalaman subjektif yang tidak menyenangkan mengenai kekhawatiran atau ketegangan yang berupa perasaan cemas, tegang, dan emosi yang dialami seseorang baik dalam situasi komunikasi yang bersifat formal maupun informal, komunikasi dalam kelompok atau orang dengan orang yang ditandai dengan reaksi fisik dan psikologis.

Kepercayaan diri merupakan salah satu masalah yang dihadapi bangsa kita. Banyak orang yang tidak yakin bahwa dirinya dapat melakukan sesuatu dengan kemampuannya sendiri. Untuk mencapai tujuan atau cita-cita, mereka lebih suka mengambil jalan pintas dan tidak mau berlatih atau mengasah keterampilannya yang dapat meningkatkan rasa percaya diri.

Seseorang yang kurang percaya diri akan cenderung sedapat mungkin menghindari komunikasi. Mereka takut diejek orang lain dan disalahkan. Orang yang tidak percaya diri akan lebih banyak diam. Dalam pidato, mereka akan berbicara terpatah-patah. Selain itu orang yang mengalami kecemasan di dalam berkomunikasi, akan menarik diri dalam pergaulan, berusaha sekecil mungkin untuk dapat berkomunikasi, dan hanya akan berbicara apabila terdesak saja.

Yakin akan kemampuan diri sendiri merupakan sikap positif seseorang tentang dirinya. Sehingga ia mampu sungguh-sungguh akan apa yang dilakukannya. Sikap positif yang dimiliki seseorang yang selalu berpandangan baik dalam menghadapi segala hal tentang diri dan kemampuannya. Rasa percaya diri yakin untuk melakukan sesuatu terhadap dirinya sendiri merupakan karakteristik pribadi yang di dalam dirinya terdapat keyakinan akan kemampuan diri, optimis, objektif, bertanggung jawab, rasional dan realistis.

Orang yang tidak percaya diri memiliki kecemasan berupa ketakutan kognitif, keterbangkitan syaraf fisiologis dan suatu pengalaman subjektif dari ketegangan atau kegugupan. Beberapa orang juga mengalami perasaan tidak nyaman dengan kehadiran orang lain, biasanya disertai dengan perasaan malu, yang ditandai dengan kekakuan, hambatan dan kecenderungan untuk menghindari interaksi sosial.

Kecemasan dalam berkomunikasi merupakan pengalaman pribadi yang bersifat subjektif dan tidak menyenangkan, sehingga mengenai kekhawatiran atau ketegangan yang berupa perasaan cemas, tegang, dan emosi yang dialami seseorang baik dalam situasi komunikasi yang bersifat formal maupun informal, komunikasi dalam kelompok atau orang dengan orang yang ditandai dengan reaksi fisik dan psikologis.

Kepercayaan diri muncul dari persiapan. Kepercayaan diri tidak bisa dipalsukan. Kepercayaan diri muncul dari melatih suatu keterampilan hingga menguasainya. Begitu menguasai suatu keterampilan.

Orang yang memiliki kepercayaan diri yang tinggi selalu berfikir optimis bahwa apa yang akan disampaikannya saat akan melakukan komunikasi di depan umum dapat disampaikan dengan baik serta apa yang disampaikan dapat diterima dan dipahami dengan baik oleh audiens. Sebaliknya orang yang memiliki berkepercayaan diri rendah tidak miliki sikap optimis dengan apa yang hendak disampaikannya saat melakukan komunikasi di depan umum. Mereka akan merasa bahwa apa yang akan disampaikan mereka dinilai buruk oleh para audiens atas apa yang telah disampaikannya serta merasa bahwa mereka akan menjadi bahan pembicaraan oleh audiens dan lain sebagainya. Pemikiran-pemikiran seperti ini yang kerap kali di miliki oleh orang yang memiliki kepercayaan diri rendah yang akan membuat ia mengalami kecemasan komunikasi di depan umum. 
Ahmad Syafi'i Ma'arif dalam Kuntowijoyo (1991: 520) menyebut pemikiran Islam kontemporer sebagai sebuah permulaan dan kerja kreatif untuk menciptakan tradisi Islam baru setelah umat Islam mengalami kekalahan dalam perjuangan politik. Tradisi baru itu dikatakannya sebagai lahan yang justru lebih strategis, mendasar, dan beriontrasi ke depan.

Tindakan menempatkan kembali pengertian, ungkapan dialog, dan sebagainya dari Al-Qur'an dalam konteks semantik dan historisnya, selain menjelaskan beberapa konsep kunci dengan cara baru, juga memungkinkan pemecahan beberapa persoalan yang menggelitik pemikiran Islam kontemporer, atau setidaknya -tidaknya memungkinkan kita untuk memahami baik asal-usul yang sebenarnya dari persoalan yang bersangkutan maupun bobot yang ditempatinya di dalam masalah-masalah kekinian. Itulah yang akan terlihat dala penanganan yang dipersembahkan oleh M. Khalafallah dalam Filali-Ansary (2003: 36) berpendapat ada dua persoalan sentral dalam pemikiran Islam kontemporer, yakni yang biasanya dimasukkan dalam kategori-kategori (1) hubungan antara Islam dan kemodernan dan (2) hubungan antara Islam dan negara. Dua persoalan itu kini menempati posisi utama di dalam benak orang, baik di dunia Islam maupun di dunia yang berhadapan dengannya.

\section{Kesimpulan}

Sistem teknologi informasi dan kepercayaan diri menjadi suatu kebutuhan dalam menerapkan pembelajaran agama Islam kontemporer di era globalisasi. Perkembangan sistem teknologi informasi yang selalu bergerak mesti diikuti dan diimbangi oleh umat Islam sehingga tetap menjadi manusia yang berkualitas.

Seluruh umat Islam juga harus mempunyai kepercayaan diri yang tinggi dalam mengungkapkan teknologi informasi yang di dapatkannya. Jangan takut akan kemajuan yang semakin hari semakin tak terbendung ini. Umat Islam diharapkan terus mempelajari keilmuan yang ada tentang agama Islam kontemporer sehingga bisa memanfaatkan sistem teknologi informasi sebagai pembelajaran agamanya sendiri. Sebab di era globalisasi saat ini dibutuhkan manusia yang berkualitas dalam hal kemampuan intelektual, vokal, maupun tanggung jawab kemanusiaan.

Untuk itulah umat Islam dituntut untuk dapat memanfaatkan teknologi informasi sebaik-baiknya sehingga mempunyai kepercayaan diri yang tinggi dalam mempelajari agama Islam di era globalisasi ini. Dan tidak hanya berdiam diri dan tak berani mencoba sesuatu yang baru hingga akhirnya tertinggal dan menjadi umat yang terbelakang.

Dalam mempelajari sistem teknologi informasi dan kepercayaan diri diharapkan umat Islam tidak hanya mengambil referensi semata dari satu sumber saja. Akan lebih baik dalam mempelajari sesuatu mempunyai perbandingan dengan keilmuan yang lain. Sehingga tak terjadi kesalahan dan membuat diri sendiri malu.

Diharapkan jika sudah mempelajari sistem teknologi informasi dan kepercayaan diri, seorang muslim harus mengutarakan keilmuan agamanya. Sebab jika hanya berdiam diri maka ia tak jauh beda dengan tidak percaya diri. Dibutuhkan insan yang berkualitas untuk tetap mempertahankan kemegahan sejarah agama Islam yang dipelajari secara kontemporer untuk mengimbangi pendidikan agama Islam di zaman yang semakin maju ini.

\section{Referensi}

Amsyah, Zulkifli. (2005). Manajemen Sistem Informasi. Jakarta: PT Gramedia Pustaka Utama.

Fatta, Hanif Al. (2007). Analisis \& Perancangan Sistem Informasi. Yogyakarta: CV. Andi Offset.

Filali-Ansary, Abdou. (2003). Pembaharuan Islam. Bandung: Mizan.

Jatmika, Sidik. (2010). Genk Remaja. Yogyakarta: Kanisius.

Kuntowijoyo. (1991). Paradigma Islam Interprestasi untuk Aksi. Bandung: Mizan.

Lumpkin, Aaron. (2004). You Can Be Positive, Confident, and Courageous. Jakarta: Erlangga.

Mcleod jr., Raymond dan Schell, George P. (2008). Sistem Informasi Manajemen. Jakarta: Salemba Empat.

Mulyono, Rudy. (2008). Beladiri Praktis untuk Wanita. Yogyakarta: Medpress.

Piliang, Yasfar Amir. (2003). Hantu-hantu Politik dan Matinya Sosial. Solo: Tiga serangkai.

Singleton, Hall. (2007). Informasi Techonology Auditing and Assurance (Audit Teknologi Informasi dan assuransi, Edisi 2). Jakarta: Salemba Empat.

Soedarsono, Yudistirira S.A., dan Kusuma A, Wida. (2004). Leadership Metamorfosis. Jakarta: PT Gramedia.

Suparno, Paul., DKK. (2010). Reformasi Pendidikan Sebuah Rekomendasi. Yogyakarta: Kanisius.

Widyatmadja, Josef P. (2005). Kebangsaan dan Globalisasi dalam Diplomasi, Yogyakarta: Kanisius. 